\title{
The Poverty Puddles of the Cage Fishing Community at Limboto Lake Coast, Indonesia
}

\author{
Tita Rostitawati ${ }^{1}$, Naufal Ilma Wahyuddin ${ }^{2} \&$ Muhammad Obie $^{2}$ \\ ${ }^{1}$ Department of Philosophy, State Islamic University of Sultan Amai Gorontalo, Indonesia \\ ${ }^{2}$ Department of Sociology, State Islamic University of Sultan Amai Gorontalo, Indonesia \\ Correspondence: Muhammad Obie, Department of Sociology, State Islamic University of Sultan Amai \\ Gorontalo, Indonesia. Tel: 62-81-3-5479-0642. E-mail: obiclimber@gmail.com
}

\author{
Received: March 6, 2019 \\ Accepted: April 18, 2019 \\ Online Published: May 30, 2019 \\ doi:10.5539/jsd.v12n3p82 \\ URL: https://doi.org/10.5539/jsd.v12n3p82
}

\begin{abstract}
This study analyzed the root causes of poverty in the cage fishing community at Limboto Lake; economic potentials; government programs related to poverty alleviation that has existed along with the causes of failure to exclude the cage fishing community from poverty puddles; and priority ideas from the fishing community that can overcome existing poverty puddles. Data collection was done through observation, interviews, focused group discussion, and literature review. The results showed that there are many aspects of the root causes of the poverty of fishing community at Limboto Lake coastal, namely policies that do not favor fishing community; low quality of human resources; the attitude of fast satisfied fishers; consumptive lifestyle; marketing of fish crops through intermediaries; and natural factors.

Meanwhile, the real, local potentials are fisheries potential; crafts of water hyacinth based; lake tourism; the potential of water resources; and the potential for limestone as a raw material for cement. Several government programs related to poverty reduction failed to free the cage fishermen community from the puddle of poverty. Firstly; the program is project-oriented that emphasized the project administration rather than the target of releasing fishers from poverty; secondly, elite dominations, so that sure fishermen elites more enjoy the existing programs on behalf of their community. The priority idea of the fishing community to overcome existing problems is to increase knowledge and skills. Increasing utilization of lake biological resources; open access to domestic and international markets; developing opportunities for alternative economic activities around the lake area; the establishment of a local organization of lake lovers; processing domestic waste, and assisting the business of fish cultivation in Limboto Lake.
\end{abstract}

Keywords: poverty, fishing community, community empowerment, fishers, Limboto lake

\section{Introduction}

Poverty is an excellent indicator which has been a scourge for third world countries. Likewise, for Indonesia, poverty is still the main problem. Based on the Central Statistics Agency's report as of March 2016, Indonesia's sparse population reached 27.9 million. Worse, around $62.71 \%$ or 17.5 million of these poor people live in rural areas. This fact is very ironic because efforts to reduce poverty have begun in the early 1970s, including through Community Guidance and Village Assistance programs. Efforts to reduce poverty in the 1970s were not optimal, so the number of poor people in the early 1990s rose again. Indonesia's poverty condition was worsened due to the economic crisis in 1998. However, when economic growth that had declined due to the crisis could be overcome and could be restored, poverty remained challenging to overcome.

The central government then launched various poverty reduction programs such as; Instruction of the President of Disadvantaged Villages, Improvement of Disadvantaged Village Infrastructure Development, Regional Empowerment in Overcoming the Impact of the Economic Crisis, Social Security Networks, fuel oil subsidies, Farmer Credit, Community-Based Clean Water and Sanitation Management Program, Family Hope Program, and others. Specifically, for urban areas, the central government launched the Urban Poverty Reduction Program, which was subsequently developed into the National Program for Community Empowerment in Urban Areas. Meanwhile, in rural areas, the government developed the Kecamatan Development Program, which was later developed into a National Program for Community Empowerment in Rural Areas. 
Gorontalo Province, as a region that has a high number of poor people, it does not escape the targets of the various programs mentioned above. Several poverty reduction programs in this area have existed even long before the establishment of Gorontalo province. Ironically, up to now, the percentage of poverty is still relatively high, which is in the range of $17.72 \%$ (Gorontalo Provincial Statistics Agency, 2016).

One community group that continues to struggle with the problem of poverty is the fishing community. Kusnadi (2003) explained that there are complex reasons why fishermen's poverty continues to occur; namely, there are internal causes in fishing communities, and there are external causes. Internal causes include limited human resources, the ability of business capital, relations of labor-owner fishermen, difficulties in diversifying fishing businesses and high dependence on sea occupation while the causes of external poverty are related to conditions outside the work and work activities of fishers, among others. Fisheries development policies oriented to productivity to support social, economic growth, fisheries product marketing systems that invite intermediary traders, damage to coastal and marine ecosystems. The use of fishing equipment that is not environmentally friendly, law enforcement that is weak against environmental damage, natural conditions, and seasonal fluctuations that do not allow fishers to go to the sea throughout the year.

Retno and Santiasih (1993) stated that compared to other community groups in the agricultural sector, fishermen (mainly traditional fishers) could be classified as the most deprived social layer, although it cannot be said that all fishermen are poor. The image of fisherman poverty is an irony, considering that Indonesia has a vast sea area, more extensive than the land area. Within the sea area, there are also various resources that have high economic potential, which should be utilized to ensure the welfare of the lives of fishers and their families (Imron, 2003).

Imron's research (2003) explained that the leading cause for the emergence of poverty faced by fishermen is the limitations of fishing technology. With limited technology, the dependence on the season is very high, and the catch area is also limited. As a result, the catch is also limited. Also, the condition of fisheries resources that are public property has resulted in competition for resources, so those traditional fishers will always lose in competition. This condition has resulted in fishermen's income being low. The situation is even worse for fishermen workers, who rely on profit sharing obtained from the bosses. With a profit-sharing system that tends to be unbalanced, the income gap between fishermen laborers and their managers is also unavoidable. Dependence on intermediaries is another problem faced by fishermen. As a result, the bargaining position of fishers is shallow, so the catches sold by fishermen are also valued lower than market prices. Thus, the income received by fishermen is also low.

In line with that, Goso and Anwar (2017) described that the factors that influence the poverty of traditional fishers that causes urban slums are: the quality factor of human resources; economic factors; and institutional factors. The form of poverty that occurs is natural and cultural poverty. Obie (2018a) explained fishermen poverty caused by the injustice of government policies. By giving concessions to fishpond entrepreneurs, the government destroyed the livelihoods of fishers originating from coastal resources. Meanwhile, Obie (2018b) linked fishermen's poverty due to government policies towards the Bajo tribal fishermen resettlement. The resettlement program to the land forced the Bajo tribe to change their livelihoods as fishermen to farmers on a narrow land. Changes to the livelihood base cause the Bajo tribe to have difficulty fulfilling their daily needs, so they fall into poverty. The concession policy, on the one hand, and the resettlement program, on the other hand, shows the government has usurped the customary rights of the Bajo people in the sea (Obie, 2015). As a result of the deprivation of customary rights, the Bajo tribe wallows in poverty due to the difficulty of meeting the needs of coastal resources-based living.

IDEAS (2017) concluded that all measures of poverty emphasize that poverty in rural areas must receive higher priority and attention than poverty in urban areas. A prominent characteristic of poor households is the low level of education of the household head. Both poor households in rural and urban areas are equally dependent on the informal sector, so they do not have social security. Prawoto and Basuki (2013) concluded that reducing poverty can only be done by deciding the causes of poverty itself. Mussadun and Nurpratiwi (2016) revealed that the factors causing natural fisherman poverty were seasonal factors and coastal damage. The structural poverty factor is caused by the difficulty of accessing banking capital and lack of power in determining the selling price of the catch. Whereas for cultural factors caused by the behavior of fishers who are consumptive, indebted, and not easy to save.

Retnowati (2011) stated that from an economic standpoint fishermen's income is still very low, so they are weak, this is due to limited capital, skills, pressure from capital owners (unfair fishery sharing system), fish trading or auction systems that are not transparent (no proper regulation and weak authority or government), work culture that is still traditional or conventional. Humaedi (2012) explained that even though the actual condition of 
poverty does not necessarily encourage fishers to become adherents of instrumental construction, the role of the government in stimulating traditions and traditional institutions that reduce poverty must be encouraged in the form of policies and programs.

This study focused on the cage fishing communities at Limboto Lake coast, which continues to wallow with the problem of poverty in a socio-economic way. Limboto Lake, which provides natural resources that are very potential, should be utilized by local communities for economic welfare. It is ironic when the people living on the lakeside coast which are rich in resources are socially and economically helpless. The cage business, which has long received program support from the Fisheries and Marine Service of Gorontalo Province, is unable to change the stigma of poverty in the fishing community. This study explained the roots of the problem causing poverty of the cage fishing community Limboto Lake coast. It was also explained local potential in the fishing community; government programs related to poverty reduction in the coastal area of Limboto, as well as their failure to free the cage fishing community from poverty puddles; as well as priority ideas from fishing communities that can overcome existing poverty puddles.

\section{Research Methods}

This study used a descriptive approach with qualitative data that intended to describe the results of research and try to find a comprehensive description of a situation. Descriptive approach with qualitative data was used to understand and study society in their daily lives, to identify how their experiences and behavior are shaped by the context of their lives, such as social, economic, cultural and physical contexts in their lives (Hennink et al., 2011). It is expected to answer in more detail about the common symptoms intended in a research problem concerned (Malo and Trisnaningtias, 1996).

Data collection of this research was done through observation, in-depth interviews, Focused Group Discussion, and literature review. As according to Bogdan and Taylor (1993) that qualitative methods make it possible to understand the society in a personal or group manner which reveals the world view from unknown experiences in society. Denzin and Lincoln (2000) suggest that qualitative methods that study everything in their natural context, to understand or interpret phenomena from meanings inherent in humans or researchers.

The data was in the form of primary data and secondary data. Informants, as primary data sources, were selected using the snowball technique. The snowball technique is determining samples that are initially small in number, then enlarged. It is like a rolling snowball that has become big for a long time.

Observation is making the subject of the study openly (Sugiyono, 2009). Meanwhile, in-depth interviews are conversations with specific intentions (Moleong, 2007). In addition to the techniques mentioned above, researchers also conducted a focused group discussion.

Sukmadinata (2005) explained that in-depth interviews are conducted by asking open questions, which allow respondents to provide full answers. Questions are directed at revealing the lives of informants, concepts, perceptions, roles, activities, and events experienced regarding the focus experienced. Mulyana (2004) explained that interviews are a form of communication between two people, involving a person who wants to get information from another person by asking questions based on specific goals.

The purpose of conducting interviews is among others: constructing about people, events, organizations, feelings, motivations, demands, concerns, and others (Lincoln and Guba, 1985). Meanwhile, focused group discussion method is to explore the topic of the problem in more depth through directed discussion. The secondary data was obtained through library studies needed to complete the primary data.

Qualitative data analysis techniques did the process of data analysis according to Marshall and Rossman (1995), wherein the process of analyzing qualitative research several steps need to be done, including (1) organizing data; (2) grouping data; and (3) narrative analysis.

Existing data were sorted, categorized, and grouped according to analysis needs. Data sorting was done by completing and transforming raw data written in field notes so that it became a regular report, completing information collected with other supporting sources. Patton (1990) argued that there is no correct way to organize, analyze, and interpret qualitative data.

\section{Results and Discussion}

\subsection{The Root of Problems Causing Poverty of Cage Fishing Community at Lake Limboto Coast}

Many aspects cause cages fishing communities at Limboto Like to be trapped into poverty. Based on the research results, these factors are: first, policies that are not siding with cage fishers. Unlike the agricultural sector, which has a superior program of corn agropolitan, cage fishers do not have special programs that can be 
relied upon. Cage fishers also have a different fate with capture fishers who have a particular program in the form of Mina Bahari Taxi with various assistance of fishing gear accompanying. Cage Fishermen are not touched by special government assistance. Meanwhile, cage fishers at Limboto Lake coast, which are the object of research do not have other livelihoods, other than cultivating fish in the lake or catching fish around the lake. The absence of policies that favor the cage fishing community has caused fishers to fend for themselves against the rigors of uncertain nature, so it is not uncommon for extreme weather to devastate their economic resources.

Second, the quality of human resources is low. The average education level of fishers is only the elementary school level, so it is difficult to adjust to technological developments. The community of fishermen at Limboto Lake catch fish on average with traditional tools, such as makeshift nets and fishing rods. Their catch is only enough to fulfill their food needs, such as buying rice and other necessities. Funding the school needs of children with their income on the lake is very difficult, which causes them to be trapped into endless poverty. The poverty they experienced is passed on to the next generation due to lack of education. With a low level of education, fishers also find it challenging to manage income from their fish crops. Sometimes the yield is not worth the costs they incur due to lack of careful calculations. Eventually, the situation of digging a hole in the hole accompanied their days at the lake coast. They must owe to buy seeds and feed, so when the harvest season arrives, the harvest is only enough to pay off the debt.

Third, the attitude of fishers who are fast satisfied. Satisfaction with the yields and catches of fishers contributes to the condition of poverty for the cage fishermen community. When on certain days the fishermen get enough catches, it is very likely not to go down to the lake the next day. Fishers feel enough for their catches and can fulfill their needs for several days afterward. Fishers will come back to the lake when the money from the sale of their catch has been used up. Likewise, when fish in cages have just been harvested, the tendency of fishers to prefer to relax is to enjoy the harvest. On the other hand, fishers are lazy for a while enjoying the harvest.

Fourth is a consumptive lifestyle. Consumptive and minimal investment is also found in the cage fishing community at Limboto Lake coast. The catch of lake fishers and cage harvest is more spent on consumptive needs than investment for the future. Even non-urgent items are often found in fishermen's houses, but at the same time investment in the form of financing children's education, and productive financing businesses are not done. Fishers are finally trapped into a puddle of poverty from generation to generation.

The fifth is the marketing of crops through intermediaries. Middleman is the primary choice for Limboto Lake coastal fishers to market their harvest and catch. For marketing, it is not uncommon to be carried out in a bonded system, where the harvest has not arrived, but the fishermen have been caught in debt to the middlemen. When the researcher asked the reason the fishermen do that, the fishermen explained that they are pressured by the necessities of life and the cost of purchasing fish feed. In conditions trapped in bonded systems like this, the fishermen are in a weak bargaining position. When the harvest season arrives or gets fish from fishing or nets, it must be sold to intermediaries at meager prices.

Sixth, natural factors. Essential factors also contribute significantly to the poverty of fishers at Limboto Lake coast. Through the in-depth interview method and focused group discussion, cage fishermen told how their dilemma is facing the season. Fishers live in anxiety, both during the dry season and the rainy season. When the dry season arrives, fishers are worried about the decreasing volume of lake water that is shrinking, while during the rainy season fishers are worried about the coming of floods that will destroy cages and their nets. Limboto Lake fishers often experience these two situations, so they experience crop failure. As a result, fishers cannot afford working capital loans to intermediaries.

\subsection{Local Potentials of Cage Fishing Community at Limboto Lake Coast}

In various problems that plagued the fishing community of Limboto Lake, some potentials can be relied on by the fishing community in sustaining life. Note from the Ministry of Environment (2014), showed that there are 12 species of fish inhabiting Lake Limboto, where 4 of them are endemic. These types can be seen in the following table 1 . 
Table 1. Typical fish types in Limboto lake

\begin{tabular}{|c|c|}
\hline Latin Name & Indonesian Name \\
\hline Uphiocara poroceplrala *) & Payangka \\
\hline \multicolumn{2}{|l|}{ Uphiocara sp. *) } \\
\hline Glossogobius giurus *) & Manggabai \\
\hline Anguilla $s p *)$ & Belut \\
\hline Pertunnus sp. & Kepiting (air tawar) \\
\hline Channa striata $* * *$ ) & Gabus \\
\hline Trichogaster pectoralis $* * *)$ & Mujair \\
\hline Oreochromis mossambicus ***) & Sepat Siam \\
\hline Osteochilus hasselti**) & Nilem \\
\hline Cyprinus carpio***) & Mas \\
\hline Puntius gonionotus**) & Tawes \\
\hline Oreochromis niloticus ${ }^{* *}$ ) & Nila \\
\hline
\end{tabular}

Source: Ministry of Environment (2014)

Ket. *): Endemic types

**): Type of introduction results

***): Type of introduction results that developed well

Data on fisheries resources as described above reinforce the results of Suryandari and Krismono's (2008) study which concluded that the diversity of fish species in the waters of Limboto Lake recorded 11 species belonging to six families. Based on the composition of the catch, payangka, manggabai, and saribu fishes are the fishes with the highest composition. Most of the fish species are introduced fishes, while includes native fishes are payangka and manggabai. Fishes in Limboto Lake have the potential to be consumption fishes, ornamental fishes, or both.

The waters of Limboto Lake are overgrown with water hyacinth plants. Although its presence in Limboto Lake is much worried by many because it can accelerate siltation of lakes, this water hyacinth plant has enormous potential. Some research results show that water hyacinth processing has high economic value. With these high economic values, water hyacinth can be a source of community livelihood. Pasaribu and Sahwalita (2006) concluded that technically, the processing of water hyacinth as a raw material for art paper is straightforward to do. The industry of art paper crafts from water hyacinth is prospectively developed around the lake as ethnic souvenirs.

Ratnani et al. (2010) concluded that tofu wastewater treatment could be done by using water hyacinth. Hendra (2011) concluded that water hyacinth could be used as raw material for briquettes. The best type of briquette is water hyacinth mixed briquettes with water hyacinth powder. Retnoningrum Research (2011) on the topic "Utilization of Water Hyacinth as a Handicraft Product: A Case Study in the Syarina Young Works KUPP Production of Kebondowo Village, Banyubiru Sub-District" showed the facts that KUPP Karya Muda Syarina Production uses the main ingredients of water hyacinth stems producing around 50 species handicrafts in the form of functional products and decorative products. Functional products include boxes, jars, and rugs, while decorative products include calligraphy, painting, and miniature wall hangings. The products produced are both high quality and less quality. Quality products include storage boxes, bags, paintings, locomotive miniature, and cars miniature, because of the shape that is suitable for use, the design is diverse, the colors and beautiful decoration. Fewer quality products include file boxes, multipurpose containers, slippers, and trash cans because they do not have an attractive design, less proportional shape, and the decoration is too simple.

Another potential for Limboto Lake is very promising tourism. The Limboto Lake area which has been designated as an object of tourism by Gorontalo regional government is the Soekarno Site and Pentadio Resort. There are still many other areas in Limboto Lake which are also potential to be developed as tourism areas, including Dembe Pier in Dembe I Village, West City Subdistrict, Gorontalo City, Iluta Pier in Iluta Village, Batudaa District, Gorontalo Regency, and Cultivation Area which is spread along the lake in the area of 
Gorontalo City and in Gorontalo Regency. Besides, the abundant potential of water resources in Limboto Lake can be used as a source of clean water, irrigation sources, flood control, and water sports.

There is still another potential in Limboto Lake, namely limestone. Kusdarto's research (2006) concluded that the total distribution of limestone (clastic limestone and reef limestone) in the Limboto region and its surroundings 14,073 hectares with hypothetical resources around $5,224,550,000 \mathrm{~m}^{3}$ or $14,253,563,500$ tons rounded up 14 billion tons. The Limboto clay is generally brown and sandy lake sediment. The distribution area is around 3,000 hectares, and the average thickness is $20 \mathrm{~m}$, inferred resources are around 600 million $\mathrm{m}^{3}$ or 1.2 billion tons. With these resources, the life span of the cement plant will be more than 100 years, with the production of 2.5 million tons of cement per year.

\subsection{Various Government Programs at Lake Limboto Coast and Its Failure to Free the Cage Fishing Community from Poverty Puddles}

Based on field data, various poverty reduction programs that have existed Limboto Lake coast are joint business groups, net assistance, the national program for community empowerment, the village fund program, and the family hope program. Nevertheless, the various programs failed to free the cage fishing community from poverty puddles. It is due to at least two things. First, the program is project oriented. The existing program is given to fishing communities who are more concerned with project administration than the target of freeing fishers from poverty. In this case, poverty is more maintained as a project field which is used as a source of the budget every year. Second, the implementation of a program dominated by the elite. Sure, fishermen elites more enjoy existing programs on behalf of their communities. As a result, the elite of fishers lives prosperously from an economic standpoint, while community members who do not have access wallow in their poverty.

Setiadi and Kolip (2011) identified two critical factors causing the failure of poverty alleviation programs in Indonesia, namely: 1) poverty reduction programs tend to focus on social assistance programs for the poor; 2) lack of understanding of various parties regarding the causes of poverty, so that poverty programs are not based on poverty issues whose causes vary locally.

Huraerah (2013) states that the poverty reduction strategy that has been implemented so far clearly shows some mistakes, among others: First, it is still oriented towards the economic aspects rather than the multidimensional aspect. The strategy of poverty reduction policies with a focus on attention to the economic aspects has proven to be a failure because poverty alleviation reduced in economic matters will not represent the real problem of poverty. Second, it is more charitable (generosity) compared to productivity. The strategy for poverty alleviation policies, which are only based on charity, will not be able to generate encouragement from the poor themselves to make efforts and try to overcome the poverty they face. They will always depend on the assistance given by other parties. Third, positioning the poor as the object rather than the subject. Fourth, the government is still the ruler of the facilitator. In handling poverty, the government still acts as a ruler who often intervenes too broadly in the lives of poor people. Such actions ignore the potential (no matter how small the potential) that is owned by the poor. On the contrary, the government should act as a facilitator, whose job is to develop their potential.

Furthermore, Huraerah (2013) identified several factors that cause the poverty reduction policy strategy to be ineffective. First, lack of coordination among institutions involved in dealing with the problem of poverty, the existence of a variety of indicators of poverty, invalid poverty data, and indications of corruption, collusion, and nepotism in the distribution of poverty alleviation programs. Second, the database of the number of poor people is still weak. The database that serves as the primary data for various poverty reduction efforts has not been able to provide accurate and accountable data. Third, there is no synergy of directed, integrated, and sustainable poverty reduction programs as a result of the existence of sectoral egos and overlapping basic tasks and functions between the regional work units. Fourth, poverty reduction programs are still marked by indications of corruption, collusion, and nepotism in the distribution of aid to needy families, both by officers and by the community itself. It causes the poverty reduction program to be misdirected.

Muslim (2017) who examined the failure of the National Program for Community Empowerment in Building Independence of the Poor concluded that the main contributing factor to the failure of the National Program for Community Empowerment in developing the independence of the poor is the poor performance of facilitators and stakeholders' understanding of program objectives. The poor performance of the facilitator can be seen from the unwillingness to implement the program according to the procedures outlined, work pragmatically by prioritizing the results of the process, and not performing their roles, duties, and functions correctly as community facilitators, both in planning, implementing and evaluating programs. Errors of stakeholders understand the program objectives appear in the selection of program priorities. The programs chosen tend to lead to the public interest rather than the interests of the poor. The development of road infrastructure, school 
buildings, irrigation channels that are often prioritized is an example of a program intended for the general public. Meanwhile, the construction of shops, outlets, or stalls intended for the poor to market their businesses has not been touched.

More broadly, Yasa (2008) identified the failure to build community independence because of several factors. 1) Empowerment programs dwell on rolling out funds. Because the principle is rolling, the reason people who can take part in the program are people who have productive businesses, while people who do not have productive businesses cannot take part in the program. Most poor people do not have productive businesses, so they cannot possibly take part in a revolving fund program. 2) Limited knowledge and skills also reduce opportunities for poor people to be able to participate in revolving funds. Because with limited knowledge and skills can affect the success of the program. 3) The attitude of field officers who are less severe in carrying out data collection on the poor and produces invalid data. It makes the reference data that is used as a reference for empowerment programs to be inappropriate so that empowerment does not touch the target, namely the poor. 4) The tendency to choose a target or location that enables high success, resulting in the determination of an inappropriate location. 5) The mentality of the poor who tend to accept what they are as an obstacle to empowerment programs. 6) The tendency of program forms that lead to giving 'fishes' instead of 'hook' or teaching how to fishes that are not right actually make the behavior of the community want to remain weak in order to keep getting help, not trying to escape poverty.

\subsection{Ideas for Fishing Community Priorities}

It is hoped that the fishing community can solve the poverty problems they face by exploiting the potential around them. Through the interview method and focused group discussion, the research team identified the priority ideas of the cage fishermen community. First, increasing knowledge and skills. Skill improvement can be realized through training, such as training on processing local products made from lake fishes, training on making water hyacinth-based crafts, and managing business management. With training, the fishing community hopes to process the local resources they have to improve their economic status and get out of the puddle of poverty.

Second, increasing utilization of lake biological resources. The fishing community cannot utilize lots of biological resources in Limboto Lake because of the lack of stimulus from the government. With the use of these resources, the fishing community hopes to provide economic effects that will lead them to a decent life.

Third, the opening of domestic and foreign markets. The market is crucial as an economic center. The fishing community hopes to access markets, both domestic and foreign, so that the local products they have can be marketed, without having to be mocked by middlemen.

Fourth, the development of opportunities for alternative economic activities around the lake area. The fishing community hopes that the government can encourage the growth of economic activities outside of fishing and cage cultivation. The lake tourism sector, for example, can be used as a superior program that is expected to have a dual effect on the fishing community. The fishing community hopes the government will invest funds to generate Limboto Lake-based tourism.

The fifth is the establishment of a local organization that loves Limboto Lake. The fishing community hopes that there will be an institution as a non-governmental organization (NGO) whose formation is initiated by the regional government so that it can synergize with the local government in maintaining Limboto Lake. This organization is expected to be able to connect the aspirations of the fishing community with the local government to voice the interests of the fishing community.

Sixth, processing domestic waste. The amount of waste in Limboto Lake is already worrying. Apart from being flooded when the rain falls, not a few the garbage is deliberately disposed of by the people themselves. This large amount of waste affects the quality of the waters, which can eventually cause contaminated fishes. The fishing community hopes that the local government will initiate waste management at Limboto Lake coast, whose management is handed over to the local organization. Waste that is appropriately managed aside from being a source of income for residents, it can improve the quality of the water in Limboto Lake.

Seventh, assisting the business of fish cultivation in Limboto Lake. During this time the fishing community independently sought out fish cultivation in Limboto Lake, both cages and nets. With low human resources due to limited formal education, the fishing community conducts these activities based solely on experiences passed down through generations. It makes the existing cultivation business very prone to crop failures, and when the rainy season arrives, it is often hit by floods, while when the dry season arrives, many fishes suddenly die because the volume of water decreases which results in fishes poisoning. 


\section{Conclusion}

There are many causes of cage fishing community poverty at Limboto Lake coast: i) policies that do not favor fishermen; ii) low quality of human resources; iii) the attitude of fishermen who are fast satisfied; iv) consumptive lifestyle; v) marketing of fish crops through middlemen; and vi) natural factors. Meanwhile, the real, local potentials are i) lake fisheries; ii) water hyacinth-based crafts; iii) lake tourism; iv) water resources, and $v$ ) the potential of limestone as a raw material for cement.

Several government programs related to Limbot Lake coastal poverty reduction are joint business groups, net assistance, the national program for community empowerment, the village fund program, and the family hope program. Several poverty reduction programs that have been implemented by the government failed to free the cage fishing community from poverty puddles. It is due to the existence of the first, project-oriented program. The existing programs which are given to the fishing community are more concerned with project administration than the target of releasing fishers from poverty puddles. Second, the implementation of the program dominated by the elites. Certain fishing elites more enjoy the existing program on behalf of the fishing community. As a result, the elites of fishing live prosperously from an economic standpoint, while community members who do not have access wallow in their poverty.

The priority ideas of the fishing community to address existing problems are increasing knowledge and skills. Increasing utilization of lake biological resources and open access to domestic and international markets developing opportunities for alternative economic activities around the lake area. The establishment of a local organization of Limboto Lake lovers, processing domestic waste, and assisting the business of fish cultivation in Limboto Lake.

\section{References}

Badan Pusat Statistik Provinsi Gorontalo. (2016). Indikator Penduduk Miskin. Retrieved December 29, 2017, from www.gorontalo.bps.go.id

Bogdan, R., \& Taylor, S. J. (1993). Dasar-Dasar Penelitian Kualitatif. Afandi AK (Translator). Surabaya: Usaha Nasional

Denzin, K. N., \& Lincoln, Y. S. (2000). Handbook of Qualitative Research. 2000. California (US): Sage Publication Inc

Goso, \& Anwar, S. M. (2017). Kemiskinan Nelayan Tradisional serta Dampaknya terhadap Perkembangan Kumuh. Jurnal Manajemen, 3(01), 25-36.

Hendra, D. (2011). Pemanfaatan Enceng Gondok untuk Bahan Briket sebagai Bahan Bakar Alternatif. Jurnal Penelitian Hasil Hutan, 29(2), 189-210. https://doi.org/10.20886/jphh.2011.29.2.189-210

Hennink, M., Hutter, I., \& Bailey, A. (2011). Qualitative Research Methods. London: Sage Publication.

Humaedi, M. A. (2012). Kemiskinan Nelayan: Studi Kasus Penyebab Eksternal dan Upaya Revitalisasi Tradisi Pengentasannya di Kaliori, Rembang, Jawa Tengah. J. Sosek, 7(2), 193-206. https://doi.org/10.15578/jsekp.v7i2.5685

Huraerah, A. (2013). Strategi Kebijakan Penanggulangan Kemiskinan di Indonesia. Pemberdayaan Komunitas, Jurnal Ilmu Kesejahteraan Sosial, 12(1), 3-13.

IDEAS. (2017). Peta Kemiskinan Indonesia: Kondisi, Kinerja dan Prospek Penanggulangan Kemiskinan Kabupaten-Kota. Laporan Penelitian Indonesia Poverty \& Inequality Report.

Imron, M. (2003). Kemiskinan dalam Masyarakat Nelayan. Jurnal Masyarakat dan Budaya, 5(1), 63-82.

Kementerian Lingkungan Hidup. (2014). Gerakan Penyelamatan Danau (Germadan) Limboto. Jakarta: KLH.

Kusdarto. (2006). Prospek Pemanfaatan Endapan Lempung Danau Limboto sebagai Bahan Baku Semen. Buletin Sumber Daya Geologi, 1(3), 30-34.

Kusnadi. (2003). Akar Kemiskinan Nelayan. Yogyakarta: LkiS.

Lyncoln, Y. S., \& Guba, E. G. (1985). Naturalistic Inquiry. California: Sage Publication Inc.

Malo, M., \& Trisnaningtias, S. (1996). Metode Penelitian Masyarakat. Universitas Indonesia: Pusat Antar Universitas Ilmu-Ilmu Sosial.

Marshall, C., \& Rossman, G. B. (1995). Designing Qualitative Research. California: Sage Publication Inc.

Moleong, L. J. (2007). Metodologi Penelitian Kualitatif (Edisi Revisi). Bandung: PT. Remaja Rosda Karya. 
Mulyana, D. (2004). Metodologi Penelitian Kualitatif. Bandung: PT. Remaja.

Muslim, A. (2017). Analisis Kegagalan Program Nasional Pemberdayaan Masyarakat dalam Membangun Kemandirian Masyarakat Miskin (Studi Kasus di Provinsi Daerah Istimewah Yogyakarta, Jawa Tengah, dan Jawa Timur). Jurnal Penyuluhan, 13(1), 79-87. https://doi.org/10.25015/penyuluhan.v13i1.14524

Mussadun, \& Nurpratiwi, P. (2016). Kajian Penyebab Kemiskinan Masyarakat Nelayan di Kampung Tambak Lorok. Jurnal Perencanaan Wilayah dan Kota, 27(1), 49-67. https://doi.org/10.5614/jrcp.2016.27.1.5

Obie, M. (2015). Perampasan Hak Ulayat Pesisir dan Laut Komunitas Suku Bajo (Kasus Pengelolaan Sumber Daya Pesisir dan Laut di Teluk Tomini. Bogor: Disertasi Sekolah Pascasarjana IPB. https://doi.org/10.15294/paramita.v25i1.3422

Obie, M. (2018a). Exploitation of Coastal and Marine Resources Along Tomini Bay: Livelihood Base Versus Concession Rights. Masyarakat, Kebudayaan dan Politik, 31(1), 36-45. https://doi.org/10.20473/mkp.V31I12018.36-45

Obie, M. (2018b). The Impact of Resettlement on Livelihood of the Bajo Tribe Community (A Case in Tomini Bay, Indonesia). Australian Journal of Basic and Applied Sciences, 12(5), 12-16.

Pasaribu, G., \& Sahwalita. (2006). Pengolahan Enceng Gondok Sebagai Bahan Baku Kertas Seni. Makalah Utama pada Ekspose Hasil-Hasil Penelitian Konservasi dan Rehabilitasi Sumberdaya Hutan. Padang, 20 September.

Patton, M. Q. (1990). Qualitative Evaluation and Research Method (2nd ed.). Newbury Park, CA: Sage Publication, Inc.

Prawoto, N., \& Basuki, A. T. (2013). Penyusunan Indikator dan Pemetaan Kantong Kemiskinan di Kabupaten Kulon Progo D.I. Yogyakarta. Yogyakarta: Laporan Akhir Hibah Bersaing UMY.

Rapitasari, D., \& Amirullah. (2016). Iptek Bagi Masyarakat Pemberdayaan Usaha Kerajinan Tangan Enceng Gondok Sulam Pita Bernilai Ekonomi Tinggi di Kelurahan Kebraon Kecamatan Karangpilang Kota Surabaya. Prosiding Seminar Nasional Ekonomi dan Bisnis.

Ratnani, R. D., Hartati, I., \& Kurniasari, L. (2010). Pemanfaatan Enceng Gondok untuk Menurunkan Kandungan COD (Chemical Oxygen Demond), pH, Bau, dan Warnah pada Limbah Cair Tahu. Semarang: Laporan Penelitian Terapan Fakultas Teknik Universitas Wahid Hasyim.

Retno, W., \& Santiasih. (1993) Pengembangan Desa Pantai, dalam Mubyarto et al., Dua Puluh Tahun Penelitian Pedesaan. Yogyakarta: Aditya media.

Retnoningrum, R. A. (2011). Pemanfaatan Enceng Gondok sebagai Produk Kerajinan: Studi Kasus Di KUPP Karya Muda Syarina Production Desa Kebondowo Kecamatan Banyubiru. Semarang: Skripsi UNNES.

Retnowati, E. (2011). Nelayan Indonesia dalam Pusaran Kemiskinan Struktural (Perspektif Sosial, Ekonomi dan Hukum). Perspektif, XVI(3), 149-159.

Setiadi, E. M., \& Kolip, U. (2011). Pengantar Sosiologi. Jakarta: Kencana Prenada Media Group.

Sugiyono. (2009). Memahami Penelitian Kualitatif. Bandung: CV. Alfabeta.

Sukmadinata, N. S. (2005). Metode Penelitian Pendidikan. Bandung: Remaja Rosda Karya.

Suryandari, A., \& Krismono. (2008). Fauna Ikan di Danau Limboto, Gorontalo. Prosiding Seminar Nasional Ikan V, Bogor, 3 Juni.

Yasa, I. G. W. M. (2008). Penanggulangan Kemiskinan Berbasis Partisipasi Masyarakat di Provinsi Bali. Input, Jurnal Ekonomi dan Sosial, 1(2), 86-91.

\section{Copyrights}

Copyright for this article is retained by the author(s), with first publication rights granted to the journal.

This is an open-access article distributed under the terms and conditions of the Creative Commons Attribution license (http://creativecommons.org/licenses/by/4.0/). 